\title{
PERBANDINGAN KONSEP PENERAPAN MEDIASI PENAL DALAM PENYELESAIAN PERKARA PIDANA DI INDONESIA DAN NEGARA LAIN
}

\author{
Febrina Hertika Rani, Luil Maknun, \\ Dosen Fakultas Hukum Universitas Muhammadiyah Palembang \\ febriinaaranii@gmail.com
}

\begin{abstract}
Abstrak
Di banyak negara ketidak puasan dan frustasi terhadap sistem peradilan pidana formal telah menumbuhkan keinginan untuk memperkuat kembali penggunaan nilai-nilai adat dan praktik peradilan tradisional dalam menanggulangi tindak pidana, memberikan kesempatan kepada pihak-pihak yang terlibat serta masyarakat untuk berperan secara aktif dalam menyelesaikan konflik dengan segala konsekuensinya. Adapun masalah yang dibahas dalam penelitian ini adalah Bagaimanakah konsep penerapan Mediasi Penal dalam penyelesaian perkara pidana di Indonesia dan di Belgia, Austria dan Jerman? Metode penelitian yang digunakan dalam penulisan ini adalah metode penelitian hukum normatif, metode penelitian hukum normatif pada dasarnya meneliti kaidah-kaidah hukum dan asas asas hukum. Penyelesaian damai / mediasi penal terhadap pelanggaran tindak pidana, melalui dua bentuk atau cara, sebagai berikut: Mediasi penal di luar proses peradilan pidana, antara lain melalui lembaga desa adat/lembaga kemasyarakatan desa; dan Mediasi penal sebagai bagian dari proses sistem peradilan pidana,mulai dari tahap penyidikan, tahap penuntutan, tahap pemeriksaan sidang pengadilan, Mediasi penal pada tahap pelaku menjalankan sanksi pidana penjara, pada tahapan ini mediasi penal dilakukan berfungsi sebagai alasan untuk menghapuskan kewenangan menjalankan sebagian pidana jika pelaku telah menjalankan sebagian pidananya. Di StGB KUHP Belgia yang menetapkan bahwa apabila pelaku member ganti rugi / kompensasi kepada korban secara penuh atau sebagian besar atau telah dengan sungguh-sungguh berusaha keras untuk memberikan ganti rugi sehingga pidananya dapat dikurangi atau bahkan dibebaskan dari pemidanaan apabila deliknya diancam dengan pidana maksimum 1 tahun penjara. Di German dalam tahap investigasi Jaksa berperan dalam menentukan apakah suatu perkara layak untuk dimediasi atau tidak. Di Austria, mediasi penal dapat dilakukan terhadap tindak pidana yang ancaman pidana penjara tidak lebih dari 5 Tahun untuk dewasa dan 10 tahun untuk anak-anak Meskipun demikian dalam perkara-perkara tertentu dapat juga digunakan untuk kasus kekerasan yang sangat berat namun mediasi penal tidakmemungkinkan untuk diterapkan apabila ada korban mati.
\end{abstract}

\section{Kata Kunci :Mediasi Penal, Pidana, Penerapan}

\section{Abstract
In many countries dissatisfaction and frustration with the formal criminal justice} system has fostered a desire to strengthen the use of traditional values and traditional justice practices in overcoming criminal acts, giving opportunities to the parties involved and the public to play an active role in resolving conflicts with all the consequences. The problem discussed in this study is: What is the concept of Penal Mediation to completion of criminal cases in Indonesia and in Belgium, Austria and Germany? The research method used in this paper is the normative legal research, it is basically examines the rules of law and the principles of the law.Penal mediation for criminal acts, have two forms or 
methods, as follows: Penal mediation outside the criminal justice process, including through customary village institutions / village community institutions; and Penal mediation as part of the criminal justice system process,starting from the investigation, the prosecution, the examination of the court hearings stage, mediation of the offense at the stage where the perpetrators carry out imprisonment sanctions, at this stage the mediation of the offense is carried out as a reason to abolish the authority to carry out some of the crimes if the offender has carried out some of his crimes.In the Belgium's StGB Criminal Code regarding that if the perpetrator gives compensation to the victim in full or in large part or has seriously tried hard to provide compensation so that the penalty can be reduced or even released from criminal punishment if the offense is threatened with a maximum 1 year in prisonIn Germany, in the investigation stage the Prosecutor plays a role in determining whether a case is suitable for mediation or not. In Austria, penal mediation can be carried out against criminal offenses which imprisonment of not more than 5 years for adults and 10 years for children. However, in certain cases it can also be used for cases of very severe violence, but penal mediation does not allow for applied when there are dead victims.

\section{Keyword : Penal Mediation, Criminal, Implementations}

\section{A. Latar Belakang}

Kebiasaan pola penyelesaian sengketa di Indonesia sepenuhnya menjadi kewenangan pengadilan. Setiap ada sengketa, pengadilanlah yang menentukan bagaimana keputusan atau penetapannya. Hal ini memang sesuai dengan aturan perundangundangan yang berlaku, karena semua sengketa diselesaikan melalui pengadilan. Indonesia menyiapkan Hukum Acara dengan sangat ketat bahkan hukum formil itu dimasukkan ke dalam hukum publik. Di samping itu juga dalam bidang hukum acara Perdata disebutkan hakim atau pengadilan harus bersikap pasif, hanya menunggu keluhan dan tuntutan pihak yang berkepentingan sebab tanpa tuntutan, pengadilan tidak dapat berbuat apapun. Disebutkan pula hakim cukup menemukan kebenaran formal saja. Akan tetapi akhir-akhir ini telah muncul pola penyelesaian, melalui tawar menawar penyelesaian, yang kadang kala telah dirancang sebelum mereka bersengketa, yang disebut mediasi. Cara seperti ini pula dapat mengurangi beban pengadilan, Pengadilan Tinggi dan Mahkamah Agung. ${ }^{1}$

\footnotetext{
${ }^{1} \mathrm{Hj}$. Lilik Prihatini,"Perspektif Mediasi Penal Dan Penerapannya Dalam Perkara
}

Pandangan konvensional atas penyelesaian hukum terhadap pelanggaran pidana masih memegang paradigma lama bahwa perkara pidana tidak dapat diselesaikan di luar proses pengadilan. Namun dalam berbagai pra ktik penegakan hukum, penyelesaian kasus pidana di Indonesia ternyata tidak jarang diselesaikan diluar proses pengadilan, misalnya melalui diskresi aparat penegak huku$\mathrm{m}$, mekanisme perdamaian, lembaga adat dan sebagainya.

Penyelesaian pada konflik - konflik yang terjadi di dalam masyarakat dapat dilakukan dengan dua pilihan, yaitu dengan jalur litigasi dan non-litigasi. Jalur litigasi merupakan cara penyelesaian masalah melalui jalur Pengadilan, sedangkan nonlitigasi merupakan cara penyelesaian masalah di luar Pengadilan. Dalam perspektif hukum

Pidana”, Pakuan Law Review,Volume 1, Nomor 1, Januari-Juni 2015, hlm 1-45

${ }^{2}$ Tri Harnowo, "Eksistensi Mediasi Penal

dalam Penyelesaian Pelanggaran Pidana

Kekayaan Intelektual

“,https://www.hukumonline.com/berita/baca/lt5b6 3f97258b43/eksistensi-mediasi-penal-dalampenyelesaian-pelanggaran-pidana-kekayaanintelektual-oleh triharnowo/, diakses tanggal 15 November 2019. 
pidana di Indonesia ini sudah mengenal penyelesaian perkara pidana di luar pengadilan, atau sering disebut dengan Alternaive Dispute Resolution. ${ }^{3}$ Di banyak negara ketidak puasan dan frustasi terhadap sistem peradilan pidana formal telah menumbuhkan keinginan untuk memperkuat kembali penggunaan nilai-nilai adat dan praktik peradilan tradisional dalam menanggulangi tindak pidana, memberikan kesempatan kepada pihak-pihak yang terlibat serta masyarakat untuk berperan secara aktif dalam menyelesaikan konflik dengan segala konsekuensinya. Restorative justice mengutamakan pendekatan dengan keterlibatan para pihak secara aktif dalam menyelesaikan konflik. Menurut Eva Achjani Zulfa bahwa keadilan Restoratif adalah sebuah konsep pemikiran yang merespon pengembangan sistem peradilan pidana Dengan menitikberatkan kepada kebutuhan pelibatan masyarakat dan korban yang dirasa tersisihkan dengan mekanisme yang bekerja pada sistem peradilan pidana yang ada pada saat ini. ${ }^{4}$

Mediasi penal pada tingkat internasional telah lama dikenal dalam beberapa konferensi misalnya konferensi PBB ke-9 tahun 1995 khususnya yang berkorelasi dengan manajemen peradilan pidana (Dokumen A/CONF 1969/6) disebutkan perlunya semua negara mempertimbangkan "privatelizing some law enforcement and justice function" and alternative dispute resolution / $A D R$ ) berupa mediasi, konsiliasi, restitusi dan kompensasi dalam sistem peradilan pidana. $^{5}$

\footnotetext{
${ }^{3}$ Cacuk Sudarsono "Pelaksanaa Mediasi Penal Dalam Penyelesaian Tindak Pidana Penganiayaan", UNNES LAW JOURNAL, Vol.4 Nomor 01, 2015, hlm.20-34.

4 Eva Achjani Zulfa, Pergeseran paradigma pemidanaan, Lubuk Agung, Bandung, 2011, hlm: 65

${ }^{5}$ Mulyadi, Lilik Kompilasi hukum pidana dalam perspektif teoritis dan praktik peradilan, perlindungan korban kejahatan, sistem peradilan dan kebijakan pidana, filsafat pemidanaan serta upaya hukum peninjauan kembali oleh Korban kejahatan, Mandar Maju, Bandung, 2010 ,hlm.15
}

\section{B. Rumusan Masalah}

1. Bagaimanakah konsep penerapan Mediasi Penal dalam penyelesaian perkara pidana di Indonesia?

2. Bagaimanakah konsep penerapan Mediasi Penal dalam penyelesaian perkara pidana di Belgia, Austria dan Jerman?

\section{Tujuan Permasalahan}

Suatu penelitian ilmiah harus mempunyai tujuan yang jelas dan merupakan pedoman dalam mengadakan penelitian, sehingga dapat menunjukan kualitas dari penelitian tersebut. Berdasarkan permasalahan yang telah dirumuskan diatas, maka tujuan yang hendak dicapai dalam penelitian ini adalah:

a. Mengetahui konsep penerapan Mediasi Penal dalam penyelesaian perkarapidana di Indonesia;

b. Mengetahui konsep penerapan Mediasi Penal dalam penyelesaian perkara pidana di Belgia, Austria dan Jerman;

\section{Metode Penelitian}

Metode penelitian merupakan salah satu cara yang ditempuh dalam memecahkan suatu permasalahan yang menjadi objek penelitian. Selaras dengan tujuan yang bermaksud memngetahui konsep penerapan Mediasi Penal dalam penyelesaian perkara pidana di Indonesia dan dibeberapa Negara lain seperti Belgia, Austria dan Jerman maka penulis menggunakan metode penelitian sebagai berikut:

Jenis penelitian yang digunakan dalam penelitian ini ialah jenis penelitian Metode penelitian yang digunakan dalam penulisan ini adalah metode penelitian hukum normatif, metode penelitian hukum normatif pada dasarnya meneliti kaidah-kaidah hukum dan asas asas hukum ${ }^{6}$. Penelitian

\footnotetext{
${ }^{6}$ Bagir Manan, "Penelitian Terapan di Bidang Hukum", makalah, disampaikan pada Lokakarya Peranan Naskah Akademis Dalam Penyusunan Peraturan Perundang-undangan, BPHN, Jakarta, 9 - 11 November 1993, hlm.7.
} 
normatif akan mencoba mene-mukan suatu aturan hukum, prinsip hukum, maupun doktrin hukum guna menjawab isu hukum yang dihadapi. ${ }^{7}$ Penelitian ini menelaah permasalahan dengan berpedoman pada data sekunder yang dilakukan dengan studi pustaka terhadap bahan-bahan hukum dan bahan nonhukum yang berkaitan dengan judul penelitian. Bahan hukum sekunder yang dimaksud adalah doktrin, ajaran para ahli tentang penataan ruang dan kearifan lokal serta aspek hukum terkait, hasil karya ilmiah para ahli yang dimuat di jurnal ilmiah, berita-berita dan hasil wa-wancara pihak terkait. ${ }^{8}$

\section{E. HASIL DAN PEMBAHASAN}

\section{PENERAPAN MEDIASI PENAL DALAM PENYELESAIAN PERKA- RA PIDANA DI INDONESIA}

Di mana ada masyarakat maka di situ ada peradilan, atau setidak-tidaknya di mana ada masyarakat di situ ada mekanisme penyelesaian perkara.Sehingga tidaklah heran ketika Hilman Hadikusuma, menyatakan bahwa peradilan adat di Indonesia sudah ada sejak dahulu kala, sebelum masa kejayaan kerajaan- kerajaan Hindu-Budha di Indonesia. ${ }^{9}$

Mediasibukanlah cara baru dalam menyelesaikan sengketa di Indonesia.Walaupun terjadi dari berbagai suku yang berbeda adat, bahasa, dan cara penyelesaian sengketa, akan tetapi Indonesia mempunyai persamaan dasar dalam menyelsesaikan semua jenis sengketa publik maupun privat yaitu mekanisme musyawarah mufakat. Mekanisme ini sama dengan esensi mediasi di mana para pihak berkompromi untuk

\footnotetext{
${ }^{7}$ Ibid.

${ }^{8}$ Peter Mahmud Marzuki, Penelitian Hukum, Kencana, Jakarta, 2010, hlm.35

9 Hedar Laudjeng, Mempertimbangkan Peradilan Adat, (Jakarta: HuMa, 2003) hlm. 3
}

mencapai titik temu yang menguntungkan semua pihak hingga tercapai kesepakatan. ${ }^{10}$

Menurut Barda Nawawi Ariefpada umumnya penyelesaian sengketa di luar pengadilan hanya ada dalam sengketa perdata, namun dalam praktik sering juga perkara pidana diselesaikan di luar pengadilan melalui berbagai diskresi aparat penegak hukum atau melalui mekanisme musyawarah/perdamaian atau lembaga permaafan yang ada dimasyarakat seperti halnya musyawarah keluarga, musyawarah desa, dan musyawarah adat. Praktik penyelesaian perkara pidana di luar pengadilan selama ini tidak ada landasan hukum formalnya, sehingga sering terjadi suatu kasus secara informal telah ada penyelesaian damai (walaupun melalui mekanisme hukum adat), namun tetap saja diproses ke pengadilan sesuai hukum yang berlaku. ${ }^{11}$

Mediasi penal merupakan Alternatif penyelesaian perkara pidana di luar jalur penal. Dalam penyelesaian perkara pidana jika menempuh jalur penal biasanya selalu adanya penjatuhan pidana oleh hakim terhadap pelaku, hal ini secara filosofis kadang-kadang tidak memuaskan semua pihak, oleh karena itu perlu adanya pemikiran penyelesaian perkara pidana melalui jalur ADR (Alternative Dispute Resolution) dengan maksud supaya dapat menyelesaikan konflik yang terjadi antara pelaku dengan korban. ${ }^{12}$

Terhadap pelanggaran tindak pidana, penyelesaian damai (mediasi penal),

\footnotetext{
${ }^{10}$ Teguh Rianto S H M H, 'Pakuan Law Review Volume 1, Nomor 2, Juli-Desember 2015 e-ISSN', 1.2 (2015), 61-112.

${ }^{11}$ Barda Nawawi Arief, Mediasi Penal Penyelesaian Perkara di Luar Pengadilan, (Semarang, Penerbit Pustaka Magister, 2010), hlm. 3-4

${ }^{12}$ Sahuri Lasmadi, "Mediasi Penal Dalam
Sistem Peradilan Pidana Indonesia", https://online-

journal.unja.ac.id/jimih/article/view/530/484, diakses tanggal 15 November 2019, pukul 20.00 wib
} 
dapat dijadikan bahan kontribusi dalam pembaharuan hukum pidana, melalui dua bentuk atau cara, sebagai berikut:

1) Mediasi penal di luar proses peradilan pidana, antara lain melalui lembaga desa adat/lembaga kemasyarakatan desa, diperlukan landasan hukum berupa kebijakan atau aturan hukum yang menetapkan tentang:

a. Tindak pidana yang dapat dimediasikan di luar proses peradilan pidana;

b. Mediasi penal dilakukan oleh pihak pelaku dan korban di luar pengadilan terhadap tindak pidana tertentu diakui keabsahannya apabila dilakukan suka rela;

c. Mediasi penal difasilitasi oleh mediator diantarany struktur adat/desa;

d. Kekuatan hukum hasil kesepakatan yang dicapai oleh pihak pelaku dan korban, sebagai keputusan yang sah dan final tidak dapat diganggu gugat dan tidak perlu dikuatkan melalui penetapan pengadilan cukup apabila disahkan dengan materai dan tanda tangan semua pihak;

e. Hasil kesepakatan yang dicapai dalam mediasi penal sebagai alasan hapusnya penuntutan tindak pidana yang telah dimediasikan;

2) Mediasi penal sebagai bagian dari proses sistem peradilan pidana, sebagai berikut:

a. Mediasi penal pada tahap penyidikan tindak pidana, pada tahap ini dimungkinkan bagi penyidik untuk meneruskan atau tidak meneruskan tindak pidana ke dalam proses peradilan pidana;

b. Mediasi penal pada tahap penuntutan, setelah pelimpahan dari penyidik ke penuntut umum. Tahap ini penuntut umum tidak semestinya langsung meneruskan tindak pidana ke pengadilan melainkan mendorong para pihak untuk berdamai, atau penuntut umum dapat langsung menghentikan penuntutan apabila telah ada penyelesaian di luar proses sistem peradilan pidana / melalui penyelesaian lembaga adat/desa.

c. Mediasi penal pada tahap pemeriksaan sidang pengadilan, setelah perkara dilimpahkan ke pengadilan, hakim menawarkan alternatif penyelesaian perkara pidana dengan cara perdamaian kepada para pihak, yaitu pihak pelaku tindak pidana dan pihak korban sebelum dilakukan proses pemeriksaan di depan sidang pengadilan dengan melihat kriteria tindak pidana yang dilakukan oleh terdakwa. Mediasi ini jika mencapai kesepakatan maka hasilnya dapat digunakan sebagai alasan untuk menghapuskan menjalankan pidana bagi pelaku tindak pidana.

d. Mediasi penal pada tahap pelaku menjalankan sanksi pidana penjara, pada tahapan ini mediasi penal dilakukan berfungsi sebagai alasan untuk menghapuskan kewenangan menjalankan sebagian pidana jika pelaku telah menjalankan sebagian pidananya. ${ }^{13}$

Mediasi Penal merupakan terobosan hukum yang diterapkan oleh aparat penegak hukum dengan mengacu pada proses pendekatan Restorative Justice, mengingat terdapat tujuan untuk mendamaikan korban tindak pidana dengan pelaku tindak pidana

\footnotetext{
${ }^{13}$ Rudini Hasyim Rado, Barda Nawawi Arief, dan Eko Soponyono, “Kebijakan Mediasi Penal Terhadap Penyelesaian Konflik Sara Di Kepulauan Kei Dalam Upaya Pembaharuan Hukum Pidana Nasional", Jurnal Law Reform Program Studi Magister Ilmu Hukum Volume 12, Nomor 2, Tahun 2016 Fakultas Hukum Universitas Diponegoro, hlm 266-276.
} 
melalui mediasi guna menyelesaikan perkara, mengembalikan serta memperbaiki kerusakan dan kerugian yang ditimbulkan akibat suatu perkara pidana. Cara demikian dapat mempertemukan keluarga kedua belah pihak yaitu keluarga korban dan pelaku, atau dengan melibatkan tokoh masyarakat untuk menemukan solusi yang terbaik. ${ }^{14}$

Perkara pidana yang biasa menggunakan jalur nonlitigasi adalah perkaraperkara yang diatur dalam Pasal 310 KUHP penghinaan/pencemaran nama baik, Pasal 311 KUHP fitnah, Pasal 351 KUHP penganiayaan, Pasal 352 ayat (1) KUHP penganiyaan ringan, Pasal 359 KUHP karena kealpaan menyebabkan matinya orang,Pasal 372 KUHP penggelapan, Pasal 378 KUHP penipuan. Selain perkara- perkara tersebut di atas, perkara pidana yang diatur dalam dalam Pasal 285 KUHP perzinahan, Pasal 332 KUHPmelarikan gadis di bawah umur, Pasal 367 ayat (2) KUHP pencurian yang dilakukan oleh anggota keluarga, juga dapat diselesaikan dengan jalur itu. Beberapa perkara pidana di luar KUHP yang pernah dilakukan penyelesaian melalui jalur non litigasi adalah pemalsuan merek, Kekerasan Dalam Rumah Tangga/KDRT, dan money politic.Mediasi penal dapat menjadi jawaban untuk menyelesaikan perkara pidana dengan lebih mengedepankan kearifan lokal budaya Indonesia yaitu kekeluargaan demi tercapainya keadilan yang merata terhadap seluruh masyarakat. ${ }^{15}$

2. PENERAPAN MEDIASI PENAL DALAM PENYELESAIAN PERKARA PIDANA DI BELGIA, AUSTRIA DAN JERMAN

\footnotetext{
${ }^{14}$ Cacuk Sudarsono, Op.Cit, hlm.20-34

${ }^{15}$ Mahasiswa Reyner, Program, S Fakultas, and Hukum Universitas, 'ALTERNATIF MEDIASI PENAL DALAM SISTEM PERADILAN PIDANA DI INDONESIA Reyner Dian Adriawan Daeng Tawang A . Latar Belakang Seperangkat Norma Mengenai Apa Yang Benar Dan Salah , Yang Dibuat Dan Diakui Eksistensinya Oleh Pemerintah, Baik Yang Tertuang Dalam', 1-26.
}

Mediasi penal di tingkat internasional telah lama dikenal. Dalam beberapa konferensi seperti Konggres PBB ke-9 tahun 1995 khususnya yangberkorelasi dengan manajemen peradilan pidana (dokumen A/ CONF 169/6) disebutkan bahwa perlunya semua negara mempertimbangkan "privatizing somelaw enforcement and jus-tice functions" dan "alternative dispute resolution/ADR) berupa mediasi, konsiliasi, restitusi dan kompensasi dalam sistem peradilan pidana. KemudianKonferensi Interna-sional Pembaharuan Hukum Pidana (Inter-national Penal Reform Conference) tahun 1999 dikemukakan bahwa salah satu unsur dari agenda barupembaharuan hukum pida-na adalah perlunya memperkaya system peradilan formal dengan sistem atau mekanisme informal dengan standar hak asasi yang mengindentifikasikan sembilan strategi pengembangan dalam melakukan pembaharuan hukum pidana melalui pengembangan restorative justice, alternative dispute resolution, informal justice, alternatives to custo$\mathrm{dy}$, alternative ways of dealing with juveniles, adalah perlunya memperkaya system peradilan formal dengan sistem / mekanisme informal dengan standar hak asasi manusia yang mengindentifikasikan sembilan strategi pengembangan dalam melakukan pembaharuan hukum pidana melalui pengembangan restorative justice, alternative dispute resolution, informal justice, alternatives to custody, alternative ways of dealing with juveniles, dealing with violent crime, reducing the prison population, the proper management of prisons dan the role of civil in penal reform. Begitu juga dalam Konggres PBB ke-10 tahun 2000 (dokumen A/CONF. 187/4/Rev.3), dikemukakan bahwa untuk memberikan perlindungan kepada korban kejahatan, hendaknya diintrodusir mekanisme mediasi dan peradilan restorative. sebagai tindak lanjut pertemuan internasional tersebut mendorong munculnya dokumen internasional yang berkorelasi dengan peradilan restoratif dan mediasi dalam perkara pidana berupa the Recommendation of the Council of Eure 1999 No. 
R (99) 19 tentang "Mediation in Penal Mattres", berikutnya the EU Framework Decision 2001 tentang "the Stannding ofVictim in Criminal Proceedings" dan The UN Principles 2002 (Resolusi Ecosoc 202/12) tentang "Basic Principles on the Use Restorative Justice Programmes in Criminal Matters". Kemudian, mediasi penal ini juga dikenal dalam beberapa UndangUndang pada Negara Austria, Jerman, Belgia, Perancis dan Po-landia. ${ }^{16}$

Tujuan diberlakukannya "Penal Mediation" di Belgiauntuk memberikan kemungkinan diberikannya tanggung jawab secara moral dan ganti rugi kepada korban tindak pidana. Dan terhadap pelaku mediasi ini dilakukan dengan terapi / rehabilitasi atau melakukan kerja sosial sebagai bentuk tanggung jawabnya. ${ }^{17}$ Tahun 1994 diberlakukan The Act on Penal Mediation, Undang-undang tentang Mediasi Penal disertai dengan pedomannya (The Guideline on Penal Mediation). Dengan adanya ketentuan di dalam Undang-Undang tersebut maka Penuntut Umum diberi kebebasan yang lebih luas untuk memprioritaskan kepentingan korban, apabila pelakutindak pidana berjanji memberikan ganti rugi / kompensasi terhadap korban kejahatanmaka kasusnya dapat tidak diteruskan. Pada mulanya kewenangan Penuntut Umum untuk tidak meneruskan penuntutan karena adanya pembayaran kompensasi hanya untuk delik atau tindak pidana yang diancam maksimum 5 tahun penjara.Tahun 1990 OVA (Offender Victim arrangement) dimasukkan kedalam hukum pidana anak secara umum dan dinyatakan sebagai "a means of diversion"pada tahun 1994 ditambahkan pasal 4a kedalam StGB (KUHP) yang menetapkan bahwa apabila pelaku member

\footnotetext{
${ }^{16}$ Lilik Mulyadi, 'Mediasi Penal Dalam Sistem Peradilan Pidana Indonesia: Pengkajian Asas, Norma, Teori Dan Praktik', Yustisia Jurnal Hukum, 2.1 (2013)

$<$ https://doi.org/10.20961/yustisia.v2i1.11054>.

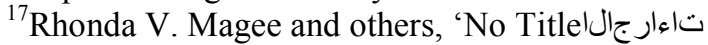
ABA Journal, 102.4 (2017), 24-25 $<$ https://doi.org/10.1002/ejsp.2570>.
}

ganti rugi/kompensasi kepada korbansecara penuh atau sebagian besar atau telah dengan sungguh-sungguh berusaha keras untuk memberikan ganti rugi sehingga pidananya dapat dikurangi atau bahkan dibebaskan dari pemidanaan apabila deliknya diancam dengan pidana maksimum 1 tahun penjara. ${ }^{18}$ Penyelesaian kasus pidana antara pelaku dan korban melalui kompensasi ini dikenal dengan istilah Täter-Opfer-Ausgleich (TOA). ${ }^{19}$

Tindakan yang dapat dimediasi dalam sistem mediasi penal di Negara German lebih beragam,contohnya pencurian, perampokan dan vandalisme baik yang dilakukan oleh anak maupun oleh orang dewasa, bahkan dibeberapa negara eropa mediasi penal telah digunakan dalam perkara kekerasan dalam rumah tangga. ${ }^{20}$

Mediasi penal di negara German ini digunakan untukmemberdayakan korban, mengurangi peran Negara dan memberdayakan masyarakat sipil, membuat warganegara berpartisipasi dalam administrasi peradilan. Mark Umbreit sebagaimana dikutip oleh Fatahillah Syukur ${ }^{21}$ dalam penelitiannya pada tahun 2001 menyatakan bahwa German adalah negara yang perkembangan program mediasi penalnya paling banyak yaitusekitar 450 program.Mediasi penal dikenal tahun 1980 dengan istilah TaterOpfer- Ausgleich (TOA) atau dikenal dengan mediasi antara pelaku dan korban, mediasi penal di German lebih memprioritaskan pendekatan pada pelaku dan bukan pada korban.100 Program pertama mediasi penal di German dimulai pada tahun 1984 dengan pilot projectuntuk menangani Anak yang berhadapan dengan hukum, sedangkan mediasi penal untuk dewasa awalnya dilakukan oleh Lembaga Bantuan Hukum atau

\footnotetext{
${ }^{18}$ Magee and others.

${ }^{19}$ Eva Achjani Zulfa, Mediasi Penal : perkembangan kebijakan hukum pidana, Makalah, Jakarta, 2011, hlm.13.

${ }^{20}$ Fatahillah, Mediasi Yudisial di Indonesia peluang dan tantangan dalam memajukan sistem peradilan, Mandar Maju, Bandung, 2012, hlm.191.

${ }^{21}$ Fatahillah, Op.Cit, hlm.64
} 
LSM Independen yang yurisdiksinya berlaku untuk semua tindak pidana termasuk dengan perkara kekerassan dalam rumah tangga pengecualian terhadap perkara yang tidak mempunyai korban secara langsung seperti peredaran narkotika, pelanggaran lalu lintasdan tindak pidana berat seperti pembunuhan. Di German digunakan dua istilah yang berbeda Restitution dan Tater Opfer-Ausgleich (TOA) atau Offender Victim Arrangement (OVA). ${ }^{22}$ Aturan Restitution tersebut dimasukkan dalam The Juvenille Penal Code of 1923 yang digunakan sebagai sanksi independen atau dengan kombinasi sanksi lain atau sebagai sarana diversi, sedangkan untuk orang dewasa perintah restitusi diakui sejak tahun 1953 sebagai sarana probation. Tahun 1994 dalam pasal 46a hukum pidana German dirumuskan ketentuan baru yang memperbolehkan Hakim untuk meringankan atau membebaskan dari hukuman kasus yang ancaman pidananya dibawah 1 tahun apabila menempuh proses mediasi penal. Kemudian sejak tahun 1998 dalam tindak pidana ringan pasal 153a Hukum Acara pidana GermanJaksa diperbolehkan untuk menunda secara formal proses penuntutan jika mediasi penal memenuhi syarat untuk dilakukan, sedangkan dalam pasal 155a hukum acara pidana German mewajibkan Jaksa dan Hakim untuk selalu melihat adanya peluang untuk menggunakan mediasi penal disetiap tahapan pemeriksaan. ${ }^{23}$

Dalam tahap investigasi Jaksa berperan dalam menentukan apakah suatu perkara layak untuk dimediasi atau tidak, ketika suatu perkara didaftarkan ke Pengadilan maka tanggung jawab tersebut berpindah ke Pengadilan. Sebelum memulai proses persidangan perkara, Majelis Hakim pemeriksa perkara yang berwenang akan memeriksa apakah perkara tersebut mempunyai peluang untukmediasi atau tidak, apabila ada peluang didamaikan maka Hakim akan segera merujuk pada proses

\footnotetext{
${ }^{22}$ Magee and others.

${ }^{23}$ Magee and others.
}

mediasi penal dan proses persidangan akan dihentikan,apabila mediasi penal tersebut mencapai kesepakatan maka akan berpengaruhterhadap putusan majelis hakim yang akan mengikuti hasil kesepakatan kecuali ada unsur melawan hokum.Proses mediasi penal yang lebih terjadi berbentuk shuttle mediationdimana korban dan pelaku tidak saling bertemu, akan tetapi mediator-hakim yang mengunjungi keduanya untuk mencapai titik temu. Beberapa syarat yang harus diperhatikan oleh Jaksa dan hakim untuk dipertimbangkan terhadap suatu kasus yang mana layak untuk menempuh mediasi penal yaitu: Kesediaan dari korban, bukan merupakan perkara yang terlalu ringan atau sepele dan adanya Kewajiban pelaku untuk bertanggung jawab.

Mediasi penal di Negara Austria didasarkan pada pasal 90g KUHAP Austria yang menyatakan bahwa:" The Public prosecutor can divert a penal case from the courts if the suspect is willing to acknowledge the deed and prepared to deal with its causes, if the suspect is prepared to undertake restitution for the possible consequences of the deed of suitable manner, in particular by providing compensation fot the consequences of the deed, and if the suspect consent to undertake any necessarry obligation which indicate a willingness to refrain in future from the type of behaviour which had led to the deed."yang menunjukkan kemauannya untuk tidak mengulangi tindak pidananya.

Awalnya mediasi penal di Negara Austria ditujukan bagi perkara tindak pidana anak saja, tetapi dalam perkembangannya mediasi penal dimungkinkan juga bagi orang dewasa. Dalam undang-undang ini ditentukan kualifikasi tindak pidana yang dapat menggunakan mediasi penal dalam penyelesaiannya yaitu ancaman pidana penjara tidak lebih dari 5 Tahun untuk dewasa dan 10 tahun untuk anak-anak Meskipun demikian dalam perkara-perkara tertentu dapat juga digunakan untuk kasus kekerasan yang sangat berat (Extremelly severe violence) namun mediasi penal tidak me- 
mungkinkan untuk diterapkan apabila ada korban mati. ${ }^{24}$

\section{F. Kesimpulan}

1. Penyelesaian damai / mediasi penal terhadap pelanggaran tindak pidana, melalui dua bentuk atau cara, sebagai berikut:

1) Mediasi penal di luar proses peradilan pidana, antara lain melalui lembaga desa adat/lembaga kemasyarakatan desa;

2) Mediasi penal sebagai bagian dari proses sistem peradilan pidana, sebagai berikut:

a. pada tahap penyidikan tindak pidana, pada tahap ini dimunkinkan bagi penyidik untuk meneruskan atau tidak meneruskan tindak pidana ke dalam proses peradilan pidana;

b. pada tahap penuntutan, setelah pelimpahan dari penyidik ke penuntut umum. Tahap ini penuntut umum tidak semestinya langsung meneruskan tindak pidana ke pengadilan melainkan mendorong para pihak untuk berdamai, atau penuntut umum dapat langsung menghentikan penuntutan apabila telah ada penyelesaian di luar proses sistem peradilan pidana / melalui penyelesaian lembaga adat/desa.

c. pada tahap pemeriksaan sidang pengadilan,setelah perkara dilimpahkan ke pengadilan,hakim menawarkan alternatif penyelesaian perkara pidana dengan cara perdamaian kepada para pihak, yaitu pihak pelaku tindak pidana dan pihak korban sebelum dilakukan proses pe- meriksaan di depan sidang pengadilan dengan melihat kriteria tindak pidana yang dilakukan oleh terdakwa. Mediasi ini jika mencapai kesepakatan maka hasilnya dapat digunakan sebagai alasan untuk menghapuskan menjalankan pidana bagi pelaku tindak pidana.

d. Mediasi penal pada tahap pelaku menjalankan sanksi pidana penjara, pada tahapan ini mediasi penal dilakukan berfungsi sebagai alasan untuk menghapuskan kewenangan menjalankan sebagian pidana jika pelaku telah menjalankan sebagian pidananya.

2. Di Belgia terhadap pelaku mediasi ini dilakukan dengan terapi / rehabilitasi atau melakukan kerja sosial sebagai bentuk tanggung jawabnya, dalampasal $4 \mathrm{a}$ kedalam StGB KUHP Belgia yang menetapkan bahwa apabila pelaku memberi ganti rugi / kompensasi kepada korban secara penuh atau sebagian besar atau telah dengan sungguh-sungguh berusaha keras untuk memberikan ganti rugi sehingga pidananya dapat dikurangi atau bahkan dibebaskan dari pemidanaan apabila deliknya diancam dengan pidana maksimum 1 tahun penjara. Di German dalam tahap investigasi Jaksa berperan dalam menentukan apakah suatu perkara layak untuk dimediasi atau tidak, ketika suatu perkara didaftarkan ke Pengadilan maka tanggung jawab tersebut berpindah ke Pengadilan. Sebelum memulai proses persidangan perkara, Majelis Hakim pemeriksa perkara yang berwenang akan memeriksa apakah perkara tersebut mempunyai peluang untukmediasi atau tidak, apabila ada peluang Hakim akan segera merujuk pada proses mediasi penal dan proses persidangan akan dihentikan.

\footnotetext{
${ }^{24}$ Magee and others.
} 
Di Austria, awalnya ditujukan bagi perkara tindak pidana anak saja, tetapi dalam perkembangannya mediasi penal dimungkinkan juga bagi orang dewasa. Dalam undang-undangnya ditentukan kualifikasi tindak pidana yang dapat menggunakan mediasi penal dalam penyelesaiannya yaitu ancaman pidana penjara tidak lebih dari 5 Tahun untuk dewasa dan 10 tahun untuk anak-anak Meskipun demikian dalam perkaraperkara tertentu dapat juga digunakan untuk kasus kekerasan yang sangat be- rat (Extremelly severe violence) namun mediasi penal tidak memungkinkan untuk diterapkan apabila ada korban mati.

\section{G. Saran}

Dengan melihat perbandingan penerapan mediasi penal yang ada di beberapa negara, sebaiknya mediasi penal segera ditetapkan pengaturannya secara rinci dan jelas. Agar penerapannya baik di dalam maupun diluar Sistem Peradilan Pidana dapat dilaksanakan secara maksimal.

\section{Daftar Pustaka}

H, Teguh Rianto S H M, 'Pakuan Law Review Volume 1, Nomor 2, Juli-Desember 2015 e-ISSN', 1.2 (2015), 61-112

Magee, Rhonda V., سدلامة. , Rhonda V. Magee, Rachael Crowder, Drew E. Winters, Emily

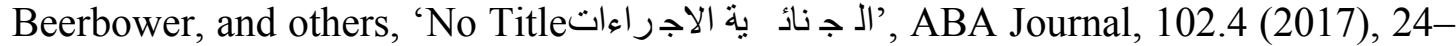
$25<$ https://doi.org/10.1002/ejsp.2570>

Mulyadi, Lilik, 'Mediasi Penal Dalam Sistem Peradilan Pidana Indonesia: Pengkajian Asas, Norma, Teori Dan Praktik', Yustisia Jurnal Hukum, 2.1 (2013) $<$ https://doi.org/10.20961/yustisia.v2i1.11054>

Reyner , Program, Mahasiswa, S Fakultas, and Hukum Universitas, 'ALTERNATIF MEDIASI PENAL DALAM SISTEM PERADILAN PIDANA DI INDONESIA Reyner Dian Adriawan Daeng Tawang A . Latar Belakang Seperangkat Norma Mengenai Apa Yang Benar Dan Salah, Yang Dibuat Dan Diakui Eksistensinya Oleh Pemerintah, Baik Yang Tertuang Dalam', 1-26

Prihatini Lilik,"Perspektif Mediasi Penal Dan Penerapannya Dalam Perkara Pidana", Pakuan Law Review, Volume 1, Nomor 1, Januari-Juni 2015

Tri Harnowo,"Eksistensi Mediasi Penal dalam Penyelesaian Pelanggaran Pidana KekayaanIntelektual“,https:/www.hukumonline.com/berita/baca/lt5b63f97258b43/e ksistensi-mediasi-penal-dalam-penyelesaian-pelanggaran-pidana-kekayaanintelektual-oleh triharnowo/, diakses tanggal 15 November 2019.

Cacuk Sudarsono "Pelaksanaa Mediasi Penal Dalam Penyelesaian Tindak Pidana Penganiayaan", UNNES LAW JOURNAL, Vol.4 Nomor 01, 2015

Eva Achjani Zulfa, Pergeseran paradigma pemidanaan, Lubuk Agung, Bandung, 2011

Mulyadi, Lilik Kompilasi hukum pidana dalam perspektif teoritis dan praktik peradilan, perlindungan korban kejahatan, sistem peradilan dan kebijakan pidana, filsafat pemidanaan serta upaya hukum peninjauan kembali oleh Korban kejahatan, Mandar Maju, Bandung, 2010

Bagir Manan, "Penelitian Terapan di Bidang Hukum", makalah, disampaikan pada Lokakarya Peranan Naskah Akademis Dalam Penyusunan Peraturan Perundangundangan, BPHN, Jakarta, 9 - 11 November 1993

Peter Mahmud Marzuki, Penelitian Hukum, Kencana, Jakarta, 2010

Hedar Laudjeng, Mempertimbangkan Peradilan Adat, (Jakarta: HuMa, 2003)

Barda Nawawi Arief, Mediasi Penal Penyelesaian Perkara di Luar Pengadilan, (Semarang, Penerbit Pustaka Magister, 2010) 
Sahuri Lasmadi, "Mediasi Penal Dalam Sistem Peradilan Pidana Indonesia", https://online-journal.unja.ac.id/jimih/article/view/530/484, diakses tanggal 15 November 2019, pukul $20.00 \mathrm{wib}$

Rudini Hasyim Rado, Barda Nawawi Arief, dan Eko Soponyono, “Kebijakan Mediasi Penal Terhadap Penyelesaian Konflik Sara Di Kepulauan Kei Dalam Upaya Pembaharuan Hukum Pidana Nasional", Jurnal Law Reform Program Studi Magister Ilmu Hukum Volume 12, Nomor 2, Tahun 2016 Fakultas Hukum Universitas Diponegoro, hlm 266-276.

Mahasiswa Reyner, Program, S Fakultas, and Hukum Universitas, 'ALTERNATIF MEDIASI PENAL DALAM SISTEM PERADILAN PIDANA DI INDONESIA Reyner Dian Adriawan Daeng Tawang A . Latar Belakang Seperangkat Norma Mengenai Apa Yang Benar Dan Salah, Yang Dibuat Dan Diakui Eksistensinya Oleh Pemerintah, Baik Yang Tertuang Dalam', 1-26.

Fatahillah, Mediasi Yudisial di Indonesia peluang dan tantangan dalam memajukan sistem peradilan, Mandar Maju, Bandung, 2012, 